\title{
HOSPITAL REPLACING OUT-PATIENT PRACTICE TO PATIENTS WITH THE VERTEBRONEVROLOLOGICAL PATHOLOGY IN UZBEKISTAN
}

\author{
Adambaev Z.I.* \\ Private neurologic clinic "Global Med System", Tashkent, Uzbekistan
}

The analysis of indicators of activity of out-patient unit of private vertebronevrological clinic "Global Med System", Tashkent, since 2006 to 2014 was carried out. The analysis of observation over 5122 patients with vertebronevrological pathology has revealed the demand of services of the specialized centers among the population as convenient and economic, with remission of liberation of the beds in a hospital for treatment of more serious patients.

In the Decree of the President of Uzbekistan Republic from September, 19th, 2007 "About the basic directions of the further excavation of reforms and realization of the Government program of development of public health services" there is a point: "... in every possible way to support and develop the private medical institutions equipped with the modern diagnostic and medical equipment, incorporating the highly skilled experts rendering to the population qualified and specialized medical aid". Besides it, the expediency of redistribution of a part of volumes of medical aid from stationary sector in the out-patient is underlined. However, hospital replacing technologies are insufficiently used now for rendering specialized medical aid.

Aim of the research. Studying the efficiency of rendering hospital replacing medical aid kinds in conditions of vertebronevrological clinic.

Material and methods. The analysis of indicators of activity of out-patient unit of private vertebronevrological clinic "Global Med System", Tashkent was carried out, for 2006-2014. Now in clinic diagnostics, out-patient and rehabilitation (specialized) treatment of vertebronevrological patients is performed. Diagnostics includes clinical-biochemical researches, US of the spinal column, joints and an internal organs, electroneuromyography, reovasography of extremities, dopplerography of the vessels of neck, head, arms and feet, electroencefalography, VNS-metry, consultation of experts. Medical process in the conditions of the clinic ambulatory consists in carrying out of the complex, specialized treatment defined by the features of pathology, accompanying diseases and contraindications. Medical treatment included non steroid anti-inflammatory drugs, myorelaxants, antiholinesterase preparations, hondroprotectors, dehydration therapy, vitamins of B group, vasoactive preparations, medical drug blockade, patients with the chronic pain can be administered antidepressants. The physiotherapy was performed including the traction of backbone, electrophoresis with medicinal preparations (extracts of the melon tree papaya Karipazim, Papain, Karipain 350 PE), thermal procedures (dyodynamic current, paraffin therapy), lazerotherapy, magnetotherapy, ultrasound therapy, amplipulsetherapy, differentiated manual massage, apparatus massage, acupuncture, manual therapy with the use of PIRM (postisometric relaxation of muscles) in certain sequence. Necessarily to the patients ortezation was done: corset selection, training of its clothing and wearing.

General characteristic of the patients. As the research material the analysis of observation over 5122 patients with vertebronevrological pathology (including, with irradiation to extremity), examined and received the out-patient treatment in specialized vertebronevrological clinic. From them were 2254 (44\%) men, 2868 (56\%) women. Middle age of the men was $44.6 \pm 2.3$ years, women $-42.5 \pm 2.1$.

Most often there were the patients with the lesion of lumbar level (lumbalgia, lumbar ishialgia) - $2151(42 \%)$ patients; neck-collar area (cervicalgia, cervicocranialgia, cervicobrachialgia) in $1430(27.9 \%)$ persons, dorsolateral thorax surfaces (thoracalgia) - in $567(11.1 \%)$, cervicothoracal localization - in $301(5.9 \%)$, neck-lumbar localization - in $673(13.1 \%)$.

During clinical examination of the all patients with the lesion of lumbar level were revealed another or other vertebral or extravertebral symptoms of various degree of expression. All

*e-mail: zufargms@mail.ru 
patients complained for pains in lumbar part of the spinal column with irradiation to one or both feet. In the neurological status the focal semiology was revealed at radicular disturbances in the form of corresponding impellent and sensitive symptoms of abaissement. In neuroortopedical status changes of the configuration of the spinal column, restriction of movement's volume in the lumbal area, tonic strain of juxtaspinal muscles, muscles basin and feet, neurodystrofic changes in interawned and other ligaments was revealed.

At cervical localization of the process patients complained for pains in cervical part of the spinal column with irradiation to occipital area, arms. In the neurological status the focal semiology was revealed at radicular disturbances in the form of corresponding impellent and sensitive symptoms of abaissement. During neuroortopedical examination change of the spinal column configuration, restriction of the movement's volume in the cervical part, tonic strain of juxtaspinal muscles, muscles of a shoulder girdle and the top extremities, neurodystrofic changes in humeral or radiocarpal joints were defined. In patients with neurovascular syndromes leading complaints were headaches which had constant compressing or squeezing character, periodically paroxysmally amplified and got arching or pulsing character. Also the typical complaint in this group in $70 \%$ of patients was the item giddiness, accompanied by instability during walking, general delicacy. Hum, ringing, stuffiness in the ears noted $45.1 \%$ of the patients. Visual disturbances in the form of grid, veil or fog before eyes, were noted in $49.1 \%$ of patients. In the neurological status of the patients, except above described symptoms, were noted others mild dispersed focal microsymptoms such as tremor of eyelids and fingers of arms, weakness of the convergence, item horizontal nystagmus, uniform revival of tendon reflexes, shaking in the Romberg's pose. In $73.3 \%$ of these patients vegetative disturbances in the kind of marble integuments, hyperhidrosis etc., were observed.

At the localization of the process in thoracal part the leading symptom in $83.6 \%$ of patients was pain in thoracal part of the spinal column or the thorax which were accompanied by pain the gleno- humeral joint or arm, numbness of the fingers of arms. Another basic symptom in $75.7 \%$ of patients was pain in the area of the heart. The heart consciousness and faults in heart area met at $47.7 \%$ of patients, feeling of shortage of air and dyspnea - in $52.2 \%$ of patients. More than the half of patients $(53.7 \%)$ noted the general delicacy, fatigability, dream disturbance, irritability. During objective examination in 52\% of patients hyperkyphosis and at in $25.5 \%$ of patients scoliosis of thoracal part of the spinal column were noted. In $74.7 \%$ of cases restriction of movement's volume in thoracal part of the spinal column were noted. Morbidity of acanthus, and also interawned ligaments on upper thoracic level (T2-T6) was met in $70 \%$ of cases. Costosternal joints at level of the $3 \mathrm{~d}-5$ th ribs were painful in $68 \%$ of patients, area of xiphoid appendix - in $66.1 \%$ of patients.

It is necessary to note, that from all patients in $48 \%$ (2458 patients) protrusions and hernias of intervertebral disks of various localization were revealed.

Apparently from Tab. 1. protrusions and hernias of intervertebral disks prevailed in lumbar $54.1 \%$, cervical $-22.9 \%$ and neck-lumbar - $18.8 \%$ parts of the spinal column. Such distribution becomes clear if to consider what load feel those or other parts of the spinal column. At the analysis of distribution of protrusions and hernias by the size, it is visible that patients with the average sizes from 3 to $6 \mathrm{~mm}-57.9 \%$ and the small sizes up to $3 \mathrm{~mm}$ - $39.8 \%$ prevail. In a small amount there were patients the big hernias - over $6 \mathrm{~mm}$ - in $12.3 \%$. It also is understood if to consider that at the sizes of hernias over $6 \mathrm{~mm}$ in patients develops the expressed radicular or radicular-tonic syndrome demanding hospitalization, and at the sizes of hernias over $10 \mathrm{~mm}$ - operative treatment is proved.

Average duration of treatment of the patients in out-patient unit of clinic was 9.9 days. In $96.0 \%$ of cases positive dynamics was received, patients were discharged from the clinic with improvement. It was promoted by careful examination of the patient with revealing accompanying diseases, by consultation of the highly skilled neurologist-vertebrologist expert with the definition of indications and contraindications to carrying out of specialized out-patient treatment. 
Distribution of patients by localization and the sizes of protrusions and hernias of intervertebral disks

\begin{tabular}{|l|l|l|l|l|}
\hline & \multicolumn{3}{|c|}{ Sizes of protrusions and hernias } & \multirow{2}{*}{ In total } \\
\cline { 1 - 4 } \multicolumn{1}{|c|}{ Localization } & \multicolumn{1}{|c|}{ To $3 \mathrm{~mm}$} & $\begin{array}{c}\text { From } 3 \text { to } 6 \\
\mathrm{~mm}\end{array}$ & \multicolumn{1}{|c|}{ Over 6 mm } & \\
\hline Cervical area & $260(10.6 \%)$ & $258(10.5 \%)$ & $45(1.8 \%)$ & $563(22.9 \%)$ \\
\hline Thoracal area & $41(1.7 \%)$ & $10(0.4 \%)$ & $0(0 \%)$ & $51(2.1 \%)$ \\
\hline Lumbar area & $122(5 \%)$ & $950(38.6 \%)$ & $258(10.5 \%)$ & $1330(54.1 \%)$ \\
\hline Cervicothoracic area & $53(2.2 \%)$ & $0(0 \%)$ & $0(0 \%)$ & $53(2.2 \%)$ \\
\hline Neck-lumbar area & $256(10.4 \%)$ & $205(8.3 \%)$ & $0(0 \%)$ & $461(18.8 \%)$ \\
\hline In total & $732(39.8 \%)$ & $1423(57.9 \%)$ & $303(12.3 \%)$ & $2458(100 \%)$ \\
\hline
\end{tabular}

For the estimation of social efficiency the analysis of satisfaction of patients taking the treatment in the conditions of an ambulatory was carried out. According to questionnaire in which 97 respondents, satisfaction of the form of work of an ambulatory was high, this form is convenient and economic for patients.

Taking into account that a considerable quantity of patients - 5122 has been effectively treated in the conditions of an ambulatory, it approximately 51 thousand days has been liberated in hospitals for treatment more serious patients.

\section{Conclusions:}

1. The organized and equipped specialized clinic completed with highly skilled experts, can

\section{REFERENCES}

1. Manvelov of h.p., Tjurnikov of Century of M. Lumbar pains (an aetiology, clinic, diagnostics and treatment). Russian medical magazine 2009q. Volume 17. №20

2. Markin S.P.modern view on a pain problem in the spinal column. Russion medical magazine 2009. Volume 17. № 20 3. Complex therapy of a pain in lumbosacral area. Prof. M.L.Kukushkin.//Treatment of nervous deseases, №2, 2008. 4. Dorsodynias in common medical practice. Prof. V.A.Parfyonov Medical Asademy by I.M.Sechenov.// render to the population the qualified and specialized ambulatory care.

2. Formation of specialized clinics is convenient and economic for patients.

3. Reception of additional effect of work of specialized (out-patient) clinics by liberating of expensive beds in the hospital for treatment more serious patients, reduction of sequence for performance of operative treatment.

The performed research testifies of the high demand among patients of services of the specialized centers and medico-organizational expediency of the further development and perfection of this kind of medical aid in conditions of vertebronevrological clinics.

Russion medical magazine. Volume 17 №4, 2009, 267-271. 5. The lumbar osteochondrosis: diagnostics, clinic and treatment//And V.Shirshov, professor M.A.Piradov. - M 9/23/2004. 6. Chou Roger, Qaseem F, V. Diagnosis and Treatment of Low Bask Pain: A Joint Clinical Practice Guideline from the American College of Physicians and tye American Pain Society Fnn Inten Med. 2008; 299 (17: 2066-2077)

7. Manchikanti L, Singh V, Pampati V, et al.//Pain Physician 2001; 4:308-316.

\title{
XÜLASO
}

\section{ÖZBӘKISTANDA VERTEBRONEVROLOJI PATOLOGIYALI PASIYENTLӘR ÜÇÜN STASIOONAR ĐVӘZEDICI AMBULATOR PRAKTIKA}

\author{
Adambaev Z.í. \\ «Global Med System» özəl nevroloji klinikası, Daşkənt, Özbəkistan
}

2006-2014-cü illər ərzində Daşkənt şəhərində, «Global Med System» özəl nevroloji klinikasının ambulator şöbəsinin fəaliyyətinin göstəriciləri tədqiq edilmişdir. Vertebronevroloji patologiya ilə 5122 pasiyentin müşahidəsinin analizi aşkar etdi ki, stasionarlarda yüksək maliyyə xərci tələb edən yataqların daha ağır xəstələr üçün saxlanılması ilə, əhali arasında rahat və iqdisadi cəhətdən sərfəli, ixtisaslaşdırılmış mərkəzlərin xidmətlərinə ehtiyac duyulur. Açar sözlər: stasionar əvəzedici ambulatoriya, vertebronevrologiya, disk yırtıqları. 


\title{
РЕЗЮМЕ
}

\section{СТАЦИОНАРЗАМЕЩАЮЩАЯ АМБУЛАТОРНАЯ ПРАКТИКА ПАЦИЕНТАМ С ВЕРТЕБРОНЕВРОЛОЛОГИЧЕСКОЙ ПАТОЛОГИЕЙ В УЗБКИСТАНЕ}

\author{
Адамбаев 3.И. \\ Частная неврологическая клиника «Global Med System», Ташкент, Узбекистан
}

Проведен анализ показателей деятельности амбулаторного отделения частной вертеброневрологической клиники «Global Med System» города Ташкента, за 2006-2014 гг. Анализ наблюдения за 5122 пациентами с вертеброневрологической патологией выявил востребованность среди населения услуг специализированных центров как удобной и экономически выгодной, с освобождением дорогостоящих коек в стационаре для лечения более тяжелых больных.

Ключевые слова: Стацонарзамещающая амбулатория, вертеброневрология, грыжи дисков.

Redaksiyaya daxil olub: 03.11.2015

Çapa tövsiyə olunub: 16.11.2015

Rəyçi: t.ü.f.d. Məmmadbəyli A.K. 